\title{
OS MUNICÍPIOS E A (IM)POSSIBILIDADE DE INSTITUIÇÃO DE NORMAS SOBRE LICITAÇÃO: UMA ANÁLISE DO RECURSO EXTRAORDINÁRIO 423560
}

\author{
Jorge Heleno Costa ${ }^{1}$ \\ Max Emiliano da Silva Sena ${ }^{2}$
}

\section{RESUMO}

Essa pesquisa objetiva, a partir da compreensão de que a Constituição da República estipula regras sobre a divisão de competências entres os entes para legislar, verificar quais são os limites dessa divisão. Tem como tema-problema a discussão sobre a limitação da competência legislativa suplementar dos Municípios em matéria licitatória, tendo como marco teórico a decisão do Recurso Extraordinário 423.560. A partir de pesquisa bibliográfica, pelo método hipotético-dedutivo, propõe-se testar a hipótese de que os Municípios podem suplementar a legislação federal em matéria licitatória.

Palavras-chave: Município; Competência legislativa suplementar; Licitação; Constituição da República Federativa do Brasil de 1988; Nepotismo.

\section{THE MUNICIPALITIES AND THE (IM)POSSIBILITY OF THE INSTITUTION OF BIDDING RULES: AN ANALYSIS OF EXTRAORDINARY APPEAL 423560}

\begin{abstract}
This research aims at verifying the limits of the division of competences between the federated entities based on the understanding of the fact that the Constitution of the Republic stipulates rules on such division. The topic-problem is the discussion on the limitation on the municipalities supplementary legislative competence, with the decision of the Extraordinary Appeal 423.560 as theoretical framework. Based on bibliographical research and following the hypothetical-deductive method, it proposes to test the hypothesis that the municipalities can supplement the federal legislation on the bidding matter.
\end{abstract}

Keywords: Municipality; Supplementary legislative powers; Bidding; Constitution of the Federative Republic of Brazil of 1988; Nepotism.

\section{INTRODUÇÃO}

\footnotetext{
${ }^{1}$ Mestre em Instituições Sociais, Direito e Democracia pela Universidade FUMEC (Linha de pesquisa: Esfera Pública, Legitimidade e Controle). Especialista em Gestão Pública e Controle com Foco em Resultados. Especialista em Gestão Pública Municipal. Especialista em Direito Público. Especialista em Direito Municipal. Advogado inscrito na OAB/MG sob o número 127214. Assessor Jurídico do Município de São Tiago/MG.

${ }^{2}$ Mestre em Direito Público pela Universidade FUMEC (Instituições Sociais, Direito e Democracia). Especialista em Direitos Humanos e Trabalho pela Escola Superior do Ministério Público da União (ESMPU). Especialista em Direito Público pela FADIVALE - Faculdade de Direito do Vale do Rio Doce. Atualmente é Procurador do Trabalho do Ministério Público do Trabalho (MPT)
} 
As ações da Administração Pública recorrentemente são pauta por parte da doutrina, bem como da jurisprudência brasileira. Na medida em que o movimento social indica uma mudança de comportamento, se faz necessária a alteração do entendimento legal a respeito de determinada temática.

Ato contínuo, num Estado que comporta uma adaptação do federalismo clássico, já que no Brasil existem três entes federados (União, Estados e Municípios), os atos e processos no âmbito administrativo, bem como as normas que os regulamentam, carecem de uma análise mais acurada com vistas a dar contornos constitucionais aos mesmos e, também, otimizar as rotinas burocráticas, afastando a possível ocorrência de erros formais ou materiais.

Partindo desses pressupostos é que a competência legislativa no âmbito municipal para suplementar a legislação federal ou estadual, naquilo que couber, será objeto de estudo.

Frente a essas questões o trabalho será norteado com a seguinte problemática: Pode o Município legislar a respeito de norma que institua vedações à participação nos certames licitatórios não previstas na Constituição da República e na legislação infraconstitucional federal?

Partindo-se dos estudos sobre a jurisprudência emanada do Supremo Tribunal Federal, especificamente o Recurso Extraordinário, $\mathrm{n}^{\circ}$ 423.560, como referencial teórico, pretende-se verificar o tema-problema posto através de pesquisa bibliográfica e documental, valendo-se, para tanto, do método hipotético-dedutivo.

De forma sumária o presente trabalho foi dividido em seis tópicos a partir da introdução, sendo que no segundo será tratado o Município e o seu dever de licitar, abordando, de forma sumária, a condição dos Municípios no sistema federativo brasileiro, ressaltando que os mesmos, assim como os demais entes, são obrigados a contratar seus serviços e adquirir seus bens por meio de processo licitatório. No terceiro serão apresentados pontos relevantes acerca da distribuição do poder normativo aos entes por parte da Constituição.

No quarto tópico o nepotismo será objeto de estudo de forma breve, enquanto que no sexto o Recurso Extraordinário no 423.560 será analisado detidamente. No sexto tópico serão apresentadas as conclusões.

O trabalho conjuga esforços no sentido de suscitar o debate acerca da possibilidade de os Municípios terem confirmada a autorização constitucional para legislar de forma suplementar, no caso em matéria licitatória, para, ao final, testar a hipótese de confirmação de que se valendo dessa autorização possa fazer com que se efetive o princípio da moralidade 
administrativa. Assim, além de pretender contribuir para o âmbito acadêmico, espera-se que a pesquisa sirva como aporte para discussões, em especial, na seara da Fazenda Pública municipal com o objetivo de otimizar a práxis administrativa dos setores de licitação.

\title{
2 OS MUNICÍPIOS E O DEVER DE LICITAR
}

O sistema de aquisição de bens e contratação de serviços por parte dos entes e órgãos da Administração Pública obedece a regramento próprio, o qual, por sua vez, está adstrito aos preceitos constitucionais. Essa é a regra disposta no art. 37, inciso, XXI, da Constituição da República de 1988, já que,

\begin{abstract}
[...] ressalvados os casos especificados na legislação, as obras, serviços, compras e alienações serão contratados mediante processo de licitação pública que assegure igualdade de condições a todos os concorrentes, com cláusulas que estabeleçam obrigações de pagamento, mantidas as condições efetivas da proposta, nos termos da lei, o qual somente permitirá as exigências de qualificação técnica e econômica indispensáveis à garantia do cumprimento das obrigações. (BRASIL, 1988).
\end{abstract}

Essa regra, por sua vez, está vinculada ao disposto no caput do mesmo artigo, especificamente quando se refere à administração pública direta e indireta de qualquer dos Poderes da União, dos Estados, do Distrito Federal e dos Municípios. (BRASIL, 1988). Como visto, portanto, tanto o Executivo, quanto o Legislativo e o Judiciário, estão adstritos à obrigatoriedade de realizar suas aquisições e contratações por meio de prévio certame licitatório.

A legislação específica aludida no inciso XXI, do art. 37, da Constituição, sem prejuízo de outras, é a Lei $\mathrm{n}^{\circ}$ 8.666, de 21 de junho de 1993, a qual “[...] estabelece normas gerais sobre licitações e contratos administrativos pertinentes a obras, serviços, inclusive de publicidade, compras, alienações e locações no âmbito dos Poderes da União, dos Estados, do Distrito Federal e dos Municípios”. (BRASIL, 1993).

Como visto, os Municípios compõem o rol daqueles entes e órgãos que estão obrigados a selecionar as propostas mais vantajosas para a administração, desde que observado, sobretudo, o princípio constitucional da isonomia, bem como outros que são inerentes ao processo licitatório.

Quanto aos Municípios, especificamente, não se pode olvidar que a própria Constituição da República arrolou-os como ente da federação de forma expressa no art. 18, quando trata da organização político-administrativa brasileira. (BRASIL, 1988). Assim, em 
que pese poder existir argumento contrário à consideração e à aceitação de que os Municípios sejam entes federativos ${ }^{3}$, o que mais importante para no presente caso é que os mesmos, por força dos dispositivos constitucionais, assim são admitidos e, consequentemente, devem seguir todos os preceitos administrativos. (COSTA, 2018, p.105-106).

Partindo dessa premissa, portanto, outro fator que não pode ser relegado para efeito de conformação da ideia de Municípios inseridos no contexto federativo brasileiro é a constatação de que dos 5.569 existentes atualmente, 81,7\% não possuem condições de gerar receitas próprias que sejam suficientes para administrar sem depender dos repasses constitucionais de outros entes. E, ainda, do mesmo universo total de Municípios, 68,3\% possuem população de até 20 (vinte) mil habitantes, fato que induz à conclusão de que a maioria dos Municípios brasileiros é de pequeno porte e, assim, tendem a possuir quadro de servidores reduzido e com pouca qualificação profissional. (COSTA; PINTO, 2019, p.24).

Embora não sejam o ponto fulcral do presente trabalho, os referidos dados são importantes para que seja possível constatar, mesmo que de forma rápida, que os Municípios na federação brasileira "concorrem" em desvantagem com os Estados e a União no quesito receitas, o que possivelmente atrai vulnerabilidade para as respectivas administrações locais, sobretudo pela deduzida ausência de qualificação profissional por parte dos servidores. Como consequência deste cenário há a probabilidade de cometimento de erros administrativos, cometidos nas diversas áreas de atuação municipal, sendo que muitos deles provavelmente ocorram por falta de conhecimento ${ }^{4}$.

Diante desta breve incursão no panorama da realidade municipal, bem como a constatação da obrigação de licitar também por parte dos Municípios, é necessário verificar como que o poder normativo previsto na Constituição de 1988 é distribuído.

\section{A DISTRIBUIÇÃO DO PODER NORMATIVO PREVISTO NA CONSTITUIÇÃO}

\footnotetext{
${ }^{3}$ José Nilo de Castro chegou a defender que "é o Município entidade condômina de exercício de atribuições constitucionais. É dizer: possui o Município dignidade constitucional. É autônomo na Constituição de hoje quanto nas anteriores, desde 1934. Falecia-lhe apenas a auto-organização. Não detém a autonomia federativa. E a autonomia é a medida constitucional da soberania, que é poder insubmetido. Não se confunde com a autonomia municipal, pois os Municípios não são entes federativos, a despeito de integrarem, como membros, a República. Integram a Federação, mas não a formam”. (CASTRO, 2006, p. 29-30).

${ }^{4}$ Apesar de a Lei de Introdução às Normas do Direito Brasileiro dispor, em seu art. $3^{\circ}$, que "ninguém se escusa de cumprir a lei, alegando que não a conhece". (BRASIL, 1942).
} 
A Constituição da República de 1988 cuidou por distinguir as competências administrativas e legislativas dos entes federados como forma de, ao fixa-las, estabelecer os limites materiais e formais de atuação de cada um daqueles. Assim, enquanto os artigos 21 e 23 da Constituição estabelecem competências administrativas, os artigos 22 e 24, por sua vez, cuidam das competências legislativas. (BRASIL, 1988).

É fato que a Constituição trata de forma geral, nos referidos dispositivos, acerca da competência da União, servindo como parâmetro para a distribuição das demais competências para Estados e Municípios. Assim, de forma bem resumida, já que não se atrela ao objetivo principal da presente pesquisa, "são reservadas aos Estados as competências que não lhes sejam vedadas por esta Constituição”, em consonância com o disposto no $\S 1^{\circ}$, do art. 25 , da Constituição da República. (BRASIL, 1988).

Por sua vez, aos Municípios, em matéria legislativa, foi outorgada a competência "[...] sobre assuntos de interesse local", bem como a capacidade de "suplementar a legislação federal e a estadual no que couber", conforme previsto nos incisos I e II, do art. 30, da Constituição. (BRASIL, 1988). Nesse sentido o constituinte originário cuidou por estabelecer um critério puramente subjetivo para os Municípios, haja vista que o interesse local é variável conforme inúmeros critérios também subjetivos, mas valer-se-á também de critérios objetivos, o que redunda na produção da mais variada legislação, já que o intento é cuidar do modo de vida social e administrativo de cada localidade.

Por óbvio que tal poder legiferante municipal não é ilimitado, encontrando óbices na própria Constituição, a qual, como já deflagrado alhures, estipulou a competência legislativa da União e, embora tenha atribuído a característica residual aos Estados, esses também não podem legislar sobre todas as matérias. Dessa forma é lícito a cada Município legislar sobre os assuntos que entender ser de seu interesse local, bem como suplementar, a partir também do seu entendimento, as legislações em âmbito federal e estadual.

A par dessa breve, mas imprescindível compressão, importa, para o presente trabalho, a observação detida no disposto no inciso XXVII, do art. 22, da Constituição da República, o qual foi alterado pela Emenda Constitucional no 19, de 04 de junho de 1998 e determina que é competência da União legislar sobre as

[...] normas gerais de licitação e contratação, em todas as modalidades, para as administrações públicas diretas, autárquicas e fundacionais da União, Estados, Distrito Federal e Municípios, obedecido o disposto no art. 37, XXI, e para as empresas públicas e sociedades de economia mista, nos termos do art. $173, \S 1^{\circ}$, III; (BRASIL, 1998). 
Eis, portanto, um traço distintivo na matéria posta em apreço, já que, como esclarecido e em princípio, aos Estados compete legislar sobre o que não é competência da União e dos Municípios, enquanto esses cuidam do denominado interesse local. Contudo, a própria Constituição autorizou que os Municípios possam suplementar a legislação federal e a estadual no que couber, ou seja, parece trata-se, novamente, de um critério subjetivo outorgado às municipalidades, as quais, para justamente poder atender os respectivos interesses locais, assim podem agir, mediante autorização constitucional.

Esse é o encaminhamento para a discussão nuclear do presente trabalho, sendo que algumas nuances das competências legislativas voltarão a ser discutidas adiante. No ponto, é necessário discorrer, mesmo que brevemente, sobre nepotismo.

\section{NEPOTISMO}

O tema nepotismo revela-se como necessário às discussões que envolvem a res publica, haja vista que o interesse a ser preservado é justamente público, ou seja, pertence a todos e, nesse sentido, qualquer tipo de favoritismo ou pessoalismo afronta a perseguição aos ditames republicanos e democráticos de um Estado.

Por nepotismo, portanto, pode-se entender, de forma direta, como a "[...] concessão de privilégios ou de cargos na administração pública sob o exclusivo influxo dos laços de parentesco". (RODRIGUES, 2012, p.205).

O favorecimento a parentes é a principal característica dessa conduta, já que quando assim age uma autoridade pública, nomeando um parente ou, de alguma forma, contribuindo para que esse seja favorecido, aquela subverte a obrigação de gerar bem-estar público em detrimento da obtenção de vantagem tipicamente ilícita ou da criação de uma possível organização paralela ao Estado com fins políticos nitidamente imorais. (ACQUAVIVA, 2009).

Já a CGU define “[...] nepotismo como a prática pela qual um agente público usa de sua posição de poder para nomear, contratar ou favorecer um ou mais parentes, sejam por vínculo da consangüinidade ou da afinidade, em violação às garantias constitucionais de impessoalidade administrativa". (CONTROLADORIA GERAL DA UNIÃO).

Sem dúvida essa é uma conduta a ser combatida pelo Estado, tanto que no Brasil o Supremo Tribunal Federal editou a Súmula Vinculante $n^{\circ} 13$, a qual determina que 
A nomeação de cônjuge, companheiro ou parente em linha reta, colateral ou por afinidade, até o terceiro grau, inclusive, da autoridade nomeante ou de servidor da mesma pessoa jurídica investido em cargo de direção, chefia ou assessoramento, para o exercício de cargo em comissão ou de confiança ou, ainda, de função gratificada na administração pública direta e indireta em qualquer dos poderes da União, dos Estados, do Distrito Federal e dos Municípios, compreendido o ajuste mediante designações recíprocas, viola a Constituição Federal. (BRASIL, 2008).

Como visto, a ideia principal de nepotismo decorre da nomeação de parentes para ocupar cargos públicos por parte de alguma autoridade pública que detenha poder para tanto. Contudo, a prática do nepotismo não se circunscreve a essas nomeações, sendo que outras condutas também podem ser enquadradas no escopo do conceito de nepotismo, como a contratação de empresas, mesmo que decorrente de processo licitatório, quando houver, de alguma forma, favorecimento a parentes de servidores da administração. Tal situação é esclarecida pela CGU:

O Decreto $n^{\circ} 7.203 / 2010$ também veda a contratação direta, sem licitação, por órgão ou entidade da administração federal, de pessoa jurídica na qual haja administrador, ou sócio com poder de direção, que seja familiar de detentor de cargo em comissão ou função de confiança que atue na área responsável pela demanda ou contratação ou de autoridade a ele hierarquicamente superior, no âmbito de cada órgão ou de cada entidade. (CONTROLADORIA GERAL DA UNIÃO).

O mencionado Decreto $\mathrm{n}^{\mathrm{o}} 7.203$, de 4 de junho de 2010, foi criado com o objetivo de dispor sobre a vedação do nepotismo no âmbito da administração pública federal e cuidou por pormenorizar e detalhar os contornos já traçados pela súmula vinculante $\mathrm{n}^{\circ} 13$ do STF (BRASIL, 2010), a qual foi abrangente no sentido de imputar “[...] efeito vinculante em relação aos demais órgãos do Poder Judiciário e à administração pública direta e indireta, nas esferas federal, estadual e municipal [...]", conforme prescreve o art. 103-A, inserido na Constituição da República de 1988 por meio da Emenda Constitucional no 45, de 30 de dezembro de 2004. (BRASIL, 2004).

A partir da orientação da CGU, portanto, amparada pelo disposto no Decreto $\mathrm{n}^{\circ}$ 7.203/2010, é possível concluir que o nepotismo não é praticado, tão somente, quando houver nomeação para se ocupar cargos públicos quando a autoridade nomeante detiver vínculos de parentesco com o nomeado.

Ocorre que da interpretação do conceito ou prática do nepotismo ainda é possível subdividi-lo, de acordo com Tauã Lima Verdan Rangel, em direto (ou próprio), indireto, cruzado e trocado. (RANGEL, 2018). 
Em breve síntese é possível esclarecer que o nepotismo direto ocorre quando a autoridade pública nomeia parente seu para ocupar cargos públicos, enquanto que para a ocorrência da modalidade indireta a autoridade nomeia parentes de seus subordinados. Já o denominado nepotismo cruzado ocorre quando houver uma troca de favores, ou seja, nomeações recíprocas de autoridades no âmbito da mesma pessoa jurídica. Por fim, o nepotismo trocado segue a mesma linha de raciocínio do nepotismo cruzado, diferenciando-se pelo fato ocorrer entre pessoas jurídicas distintas. (RANGEL, 2018).

Diante destes suficientes esclarecimentos sobre nepotismo, passar-se-á à análise do Recurso Extraordinário 423.560, cuja decisão pode ser entendida como um marco nas discussões sobre o poder normativo local dos Municípios, em especial no que diz respeito à (im)possibilidade desses suplementar a legislação federal.

\section{O STF E O PODER NORMATIVO LEGAL: ANÁLISE DO REXT 423.560}

Exercendo seu mister constitucional de guardião da Constituição da República, conforme disposto no art. 102 (BRASIL, 1988), o Supremo Tribunal Federal, pela via incidental de controle de constitucionalidade, analisou e julgou o Recurso Extraordinário ${ }^{\circ}$ 423.560, sob a relatoria do então Ministro Joaquim Barbosa, cuja ementa restou assim grafada:

EMENTA: DIREITO CONSTITUCIONAL E ADMINISTRATIVO. LICITAÇÃO E CONTRATAÇÃO PELA ADMINISTRAÇÃO PÚBLICA MUNICIPAL. LEI ORGÂNICA DO MUNICÍPIO DE BRUMADINHO-MG. VEDAÇÃO DE CONTRATAÇÃO COM O MUNICÍPIO DE PARENTES DO PREFEITO, VICEPREFEITO, VEREADORES E OCUPANTES DE CARGOS EM COMISSÃO. CONSTITUCIONALIDADE. COMPETÊNCIA SUPLEMENTAR DOS MUNICÍPIOS. RECURSO EXTRAORDINÁRIO PROVIDO.

A Constituição Federal outorga à União a competência para editar normas gerais sobre licitação (art. 22, XXVII) e permite, portanto, que Estados e Municípios legislem para complementar as normas gerais e adaptá-las às suas realidades.

O Supremo Tribunal Federal firmou orientação no sentido de que as normas locais sobre licitação devem observar o art. 37, XXI da Constituição, assegurando "a igualdade de condições de todos os concorrentes". Precedentes.

Dentro da permissão constitucional para legislar sobre normas específicas em matéria de licitação, é de se louvar a iniciativa do Município de Brumadinho-MG de tratar, em sua Lei Orgânica, de tema dos mais relevantes em nossa pólis, que é a moralidade administrativa, princípio-guia de toda a atividade estatal, nos termos do art. 37, caput da Constituição Federal.

A proibição de contratação com o Município dos parentes, afins ou consanguíneos, do prefeito, do vice-prefeito, dos vereadores e dos ocupantes de cargo em comissão ou função de confiança, bem como dos servidores e empregados públicos municipais, até seis meses após o fim do exercício das respectivas funções, é norma que evidentemente homenageia os princípios da impessoalidade e da moralidade administrativa, prevenindo eventuais lesões ao interesse público e ao patrimônio do 
Município, sem restringir a competição entre os licitantes.

Inexistência de ofensa ao princípio da legalidade ou de invasão da competência da União para legislar sobre normas gerais de licitação.

Recurso extraordinário provido. (BRASIL, STF. RExt. 423.560, Rel. Min. Joaquim Barbosa, 2012).

Para efeito de análise do referido recurso extraordinário é necessário rememorar o disposto no inciso XXI, do art. 37, da Constituição da República, o qual estabelece a obrigatoriedade de utilização do processo de licitação pública para as compras e contratações por órgãos públicos como regra.

Vale frisar que o mandamento constitucional destacado remete à observância da legislação infraconstitucional, a saber, especificamente para o caso em apreço e além da Lei no 8.666, de 21 de junho de 1993 e alterações, a Lei no 10.520, de 17 de julho de 2002, a qual “institui, no âmbito da União, Estados, Distrito Federal e Municípios, nos termos do art. 37, inciso XXI, da Constituição Federal, modalidade de licitação denominada pregão, para aquisição de bens e serviços comuns, e dá outras providências" (BRASIL, 2002), bem como os respectivos decretos regulamentadores elaborados eventualmente em cada nível federativo (federal, estadual e municipal).

No que diz respeito ao enfrentamento da problemática proposta para o presente estudo a Lei $\mathrm{n}^{\circ} 8.666 / 93$, em seu art. $9^{\circ}$, cuidou de apresentar os casos e as pessoas impedidas de participar direta ou indiretamente da licitação:

Art. $9^{\circ}$ Não poderá participar, direta ou indiretamente, da licitação ou da execução de obra ou serviço e do fornecimento de bens a eles necessários: I - o autor do projeto, básico ou executivo, pessoa física ou jurídica;

II - empresa, isoladamente ou em consórcio, responsável pela elaboração do projeto básico ou executivo ou da qual o autor do projeto seja dirigente, gerente, acionista ou detentor de mais de 5\% (cinco por cento) do capital com direito a voto ou controlador, responsável técnico ou subcontratado;

III - servidor ou dirigente de órgão ou entidade contratante ou responsável pela licitação.

$\S 1^{\mathrm{o}}$ É permitida a participação do autor do projeto ou da empresa a que se refere o inciso II deste artigo, na licitação de obra ou serviço, ou na execução, como consultor ou técnico, nas funções de fiscalização, supervisão ou gerenciamento, exclusivamente a serviço da Administração interessada.

$\S 2^{\mathrm{o}} \mathrm{O}$ disposto neste artigo não impede a licitação ou contratação de obra ou serviço que inclua a elaboração de projeto executivo como encargo do contratado ou pelo preço previamente fixado pela Administração.

$\S 3^{0}$ Considera-se participação indireta, para fins do disposto neste artigo, a existência de qualquer vínculo de natureza técnica, comercial, econômica, financeira ou trabalhista entre o autor do projeto, pessoa física ou jurídica, e o licitante ou responsável pelos serviços, fornecimentos e obras, incluindo-se os fornecimentos de bens e serviços a estes necessários.

$\S 4^{0} \mathrm{O}$ disposto no parágrafo anterior aplica-se aos membros da comissão de licitação. (BRASIL, 1993). 
No caso concreto decidido pelo Supremo Tribunal Federal a celeuma ocorreu originalmente no Município de Brumadinho, em Minas Gerais, o qual, segundo suas razões, valeu-se do seu poder atribuído pela Constituição da República para suplementar a legislação federal em matéria de licitações públicas. A suplementação efetivada pelo Município foi no sentido de criar norma que impedia a contratação com determinadas além daquelas previstas no art. $9^{\circ}$, da Lei ${ }^{\circ}$ 8.666/1993. O art. 36, da Lei Orgânica do Município de Brumadinho dispunha que

O Prefeito, o Vice-Prefeito, os Vereadores, os ocupantes de cargo em comissão ou função de confiança, as pessoas ligadas a qualquer deles por matrimônio ou parentesco, afim ou consangüíneo, até o $2^{\circ}$ grau, ou por adoção e os servidores e empregados públicos municipais, não poderão contratar com o Município, subsistindo a proibição até seis meses após findas as respectivas funções. (BRUMADINHO, 1990).

Em que pese o Município de Brumadinho ter aprovado nova Lei Orgânica em 27 de dezembro de 2018, as disposições contidas no então art. 36 foram mantidas integralmente no novo mandamento orgânico, porém agora no art. 37. (BRUMADINHO, 2018).

Ocorre que à época o então PMDB - Partido do Movimento Democrático Brasileiro ${ }^{5}$ ajuizou representação de inconstitucionalidade perante o Tribunal de Justiça de Minas Gerais alegando, em síntese, que o referido dispositivo seria inconstitucional por ter afrontado as disposições da Lei de Licitações e, em especial, pelo fato de o Município ter usurpado da competência suplementar para legislar, já que matéria licitatória seria de competência, tão somente, da União. (MINAS GERAIS, ADI 1.0000.00.287271-1/000, Rel. Des. Francisco Figueiredo, 2003).

Fato relevante nesse julgamento, ainda em âmbito estadual, é que o relator restou vencido, mesmo tendo argumentado em seu voto que

[...] após uma reflexão mais amadurecida sobre a matéria, vez que adotei posição diversa em passado recente, tenho que a norma em estudo mostra-se harmônica com o ideário constitucional do Estado, sendo forçoso interpretá-la de forma teleológica, mantendo-a integrada no ordenamento jurídico. (MINAS GERAIS, ADI 1.0000.00.287271-1/000, Rel. Des. Francisco Figueiredo, 2003).

Não satisfeita com a decisão do Tribunal de Justiça de Minas Gerais, o qual entendeu que o dispositivo orgânico era inconstitucional, a Câmara de Vereadores de Brumadinho

\footnotetext{
${ }^{5}$ Desde 19 de dezembro de 2017, em Convenção Nacional Extraordinária, o partido passou a usar a sigla MDB Movimento Democrático Brasileiro. Disponível em: https://www.mdb.org.br/estatuto/. Acesso em: 08 mar. 2019.
} 
recorreu extraordinariamente junto ao STF pleiteando a revisão daquela decisão e, consequentemente, o reconhecimento da constitucionalidade do mencionado dispositivo.

Volvendo os olhares novamente sobre o art. $9^{\circ}$ da Lei $n^{\circ} 8.666 / 1993$, verifica-se que no mesmo não há menção equivalente ao comando inserido na Lei Orgânica do Município de Brumadinho. Entretanto, parte-se do pressuposto que a hermenêutica jurídico-legal deve ser holística, de tal forma que o ordenamento jurídico deve ser perlustrado exaustivamente de modo a oferecer supedâneo legal às decisões, judiciais ou administrativas.

Diante de tal constatação e analisando também o inciso XXVII, do art. 22, da Constituição da República, talvez seja possível consignar que a semântica do referido dispositivo pode induzir à seguinte conclusão: normas gerais sobre licitação. Por sua vez, como já mencionado, o art. 30, inciso II, da Constituição da República, definiu que é competência dos Municípios, além de legislar sobre matérias de interesse local, “[...] suplementar a legislação federal e a estadual no que couber [...]”. (BRASIL, 1988).

Porém, antes de se adentrar no mérito acerca dessa disposição constitucional é preciso repisar que, em que pese entendimento diverso, considera-se que o Município é ente federativo, nos exatos termos do art. 18 c/c art. $1^{\circ}$ da Constituição da República (BRASIL, 1988). Assim, embora o art. 29, também da Constituição, tenha mencionado que o Município reger-se-á por Lei Orgânica, essa nomenclatura não retira a natureza constitucional deste arcabouço normativo, em que pese poder existir entendimento no sentido de que ao Município não foi outorgado o poder constituinte.

Ao contrário, a Lei Orgânica detém elementos suficientes para ser entendida como a "Lei Maior" do Município e, por conseguinte, sua Constituição, haja vista que todas as demais leis locais deverão respeitar os ditames orgânicos. Ademais, a Constituição do Estado de Minas Gerais, a qual dispõe sobre os Municípios, em seu art. 165, §4º́ é enfática ao determinar que "todo o poder do Município emana do povo, que o exerce por meio de representantes eleitos ou diretamente, nos termos de sua Lei Orgânica e da Constituição da República” (MINAS GERAIS, 1989).

Coadunando com tal entendimento, Pedro Lenza aduz que

Os Municípios (que por força dos arts. 1. ${ }^{\circ}$ e 18 da CF/88 fazem parte da Federação brasileira, sendo, portanto, autônomos em relação aos outros componentes, na medida em que também têm autonomia "F.A.P." — Financeira, Administrativa e Política) elaborarão leis orgânicas como se fossem "Constituições Municipais". (LENZA, 2017, p.206). 
Seguindo a mesma linha de raciocínio, Hely Lopes Meirelles também admite que a Lei Orgânica dos Municípios, a qual denomina de "Carta Própria", equivale à Constituição Municipal (MEIRELLES, 2008, p.85).

Nesse sentido, parece não haver dúvidas de que a Lei Orgânica pode ser admitida, tanto formalmente, quanto materialmente, como a Constituição Municipal e, diante dessa constatação, o respeito aos seus comandos é premissa indissociável para o exercício das atribuições político-administrativas do Município. E a partir dessa concepção, o art. 36 da Lei Orgânica do Município de Brumadinho, transcrito alhures, parece ter se ocupado, tão somente, de suplementar a legislação federal que rege a matéria licitatória ao incluir a vedação extensiva de contratar com o Município as pessoas mencionadas no referido dispositivo. Tratou-se, assim, de regra inserida no ordenamento jurídico local com o aval da Constituição da República e da Constituição do Estado, parecendo ser incabível alegação sobre sua inconstitucionalidade por supostamente apresentar vedação além da prevista no art. $9^{\circ}$ da Lei no ${ }^{\circ} 8.666 / 1993$.

Embora parecer incabível a suscitada alegação de inconstitucionalidade, o Tribunal de Justiça mineiro, ao dar guarida ao pedido do então PMDB, autorizou a manejo recursal extraordinário por parte da Câmara de Vereadores de Brumadinho e, consequentemente, revisão da matéria pelo Supremo Tribunal Federal. Segundo consta no voto do relator, Ministro Joaquim Barbosa, o qual foi acompanhado por unanimidade pela Segunda Turma do STF, restou assentado que

\begin{abstract}
[...] em face da ausência de regra geral para este assunto, o que significa dizer que não há vedação ou permissão acerca do impedimento à participação em licitações em decorrência de parentesco, abre-se campo para a liberdade de atuação dos demais entes da federação, a fim de que eles legislem de acordo com suas particularidades locais (no caso dos municípios, com fundamento no art. 30, II, da Constituição Federal), até que sobrevenha norma geral sobre o tema. (BRASIL, STF. RExt. 423.560, Rel. Min. Joaquim Barbosa, 2012).
\end{abstract}

Como asseverado pelo Ministro-relator, a Lei n ${ }^{\circ}$ 8.666/93 não cuidou por autorizar ou vedar a participação de licitantes por razões de parentesco, sendo que, portanto, a partir da autorização conferida pela Constituição da República, bem como pela respectiva Constituição do Estado, o Município pode criar regras suplementares, como as existentes no âmbito brumadinhense.

Outro ponto que merece destaque do voto do Ministro-relator diz respeito ao princípio da moralidade administrativa: 
E dentro da permissão constitucional para legislar sobre normas específicas em matéria de licitação, é de se louvar a iniciativa do Município de Brumadinho-MG de tratar, em sua Lei Orgânica, de questão das mais relevantes em nossa pólis, que é a moralidade administrativa, princípio-guia de toda a atividade estatal, nos termos do art. 37, caput da Constituição Federal. (BRASIL, STF. RExt. 423.560, Rel. Min. Joaquim Barbosa, 2012).

E continua o relator:

A proibição de contratação com o Município dos parentes, afins ou consanguíneos, do prefeito, do vice-prefeito, dos vereadores e dos ocupantes de cargo em comissão ou função de confiança, bem como dos servidores e empregados públicos municipais, até seis meses após o fim do exercício das respectivas funções, é norma que evidentemente homenageia os princípios da impessoalidade e da moralidade administrativa, prevenindo eventuais lesões ao interesse público e ao patrimônio do Município, sem restringir a competição entre os licitantes. (BRASIL, STF. RExt. 423.560, Rel. Min. Joaquim Barbosa, 2012).

Como visto, portanto, o STF, além de reconhecer a constitucionalidade do dispositivo em discussão, fez menção honrosa ao Município de Brumadinho por conter em sua Lei Orgânica dispositivo que guarda em sua essência um dos princípios elencados no art. 37 da Constituição da República, que é a moralidade administrativa. Adiante, o Supremo ainda esclareceu que a norma outrora questionada não viola a competitividade exigida para os certames licitatórios, haja vista, nesse caso, a prevalência dos princípios da moralidade e da impessoalidade.

A respeito do princípio constitucional da moralidade administrativa, é cabível o entendimento de que o mesmo é caro à construção de uma sociedade cada vez mais justa e pautada no comportamento ético de todos, sobretudo daqueles que receberam a confiança popular, por meio do voto, para ocupar cargos públicos. Nesse sentido, para Marçal Justen Filho,

Considera-se um risco a existência de relações pessoais entre os sujeitos que definem o destino da licitação e o particular que licitará. Esse relacionamento pode, em tese, produzir distinções incompatíveis com a isonomia. A simples potencialidade do dano é suficiente para que a lei se acautele. Em vez de remeter a uma investigação posterior, destinada a comprovar anormalidade da conduta do agente, a lei determina seu afastamento a priori. O impedimento consiste no afastamento preventivo daquele que, por vínculos pessoais com a situação concreta, poderia obter benefício especial e incompatível com o princípio da isonomia. O impedimento abrange aqueles que, dada a situação específica em que se encontram, teriam condições (teoricamente) de frustrar a competitividade, produzindo benefícios indevidos e reprováveis para si e para terceiro. (JUSTEN FILHO, 2010, p.163). 
Embora a lição acima seja posterior à promulgação da Lei Orgânica do Município de Brumadinho, o "constituinte" brumadinhense talvez tenha se imbuído desse espírito para editar a norma restritiva prevista no art. 36, qual seja: defender os interesses coletivos de possíveis intervenções de ordem pessoal.

Seguindo a mesma linha de raciocínio, Marçal Justen Filho ainda argumenta que

É vedado ao administrador sobrepor um interesse particular (próprio ou de terceiros)
ao interesse coletivo. Diante de conflito de interesses, o administrador deve agir com
lealdade para com o interesse coletivo. A moralidade e a probidade acarretam a
impossibilidade de vantagens pessoais extraídas pelo administrador. Por igual, estão
proibidas vantagens ou prejuízos decorrentes de preferências pessoais dos titulares
de funções públicas. Mesmo que não retirem, direta ou indiretamente, qualquer
benefício, os administradores praticam atos inválidos quando interferem no destino
da licitação para beneficiar ou prejudicar concorrente. (JUSTEN FILHO, 2010,
p.163).

Por fim, no que diz respeito à conduta dos licitantes, Marçal Justen Filho defende que

O princípio da moralidade também ser refere à conduta dos próprios participantes da licitação. A disputa deve ser honesta entre eles. Devem guardar postura moralmente correta perante os demais competidores e a Administração. A imoralidade de sua conduta acarretará seu afastamento e, eventualmente, a invalidação do procedimento. (JUSTEN FILHO, 2010, p.163).

A compreensão a ser alcançada com a exegese acerca da problemática proposta tende a inclinar no sentido de que a moralidade é um princípio bilateral no âmbito da Administração Pública, ou seja, tanto o administrador, quanto aqueles que se candidatam a contratar com aquela devem observa-lo irrestritamente.

E nesse sentido não é forçoso repisar que em todas as relações públicoadministrativistas, o Poder Público, em todas as suas esferas e por todos os seus atos, está adstrito à observância do princípio constitucional e republicano da legalidade. Portanto, como existe norma municipal cogente no sentido de elencar outras hipóteses de vedação para contratação com esse Ente, a mesma deve ser respeitada, sob pena de responsabilização caso haja desrespeito.

É preciso, ainda, destacar que as decisões dos gestores públicos devem pautar-se em ações probas, que apesar de às vezes não contemplar o interesse de um particular especificamente, guarda correção legal e harmoniosa com suas funções, bem como visam atender o interesse público. Nesse sentido, como disposto na Constituição do Estado de Minas Gerais, em seu art. 166, inciso VI, todos os Municípios mineiros têm como objetivo prioritário preservar a moralidade administrativa. (MINAS GERAIS, 1989). 
A título ilustrativo destaque-se a existência de norma semelhante vigente no Município de São Tiago, também no estado de Minas Gerais, cujo art. 144 da sua Lei Orgânica assim dispõe:

Art. 144 O Prefeito, o Vice-Prefeito, os Vereadores e os servidores municipais bem como as pessoas ligadas a qualquer deles, por matrimonio ou parentesco afim ou consanguíneo, até o terceiro grau ou por adoção, não poderão contratar com o município, subsistindo a proibição até seis meses, após findas as respectivas funções. (SÃO TIAGO, 2003).

Com pouca diferença do dispositivo brumadinhense, o dispositivo são-tiaguense também se alinha na mesma intenção daquele, visando suplementar a legislação federal e assegurar que o princípio da moralidade administrativa seja alargado, especificamente, quando das contrações e aquisições por parte do Poder Público municipal.

Por derradeiro, a pretensão de se destacar o nepotismo no transcurso do presente trabalho não foi em vão. Nesse sentido, o relator do recurso extraordinário analisado assevera que

Não é ocioso relembrar, embora não seja especificamente a hipótese dos autos, que esta Corte, no julgamento da ADC 12, rel. Min. Ayres Britto, declarou a constitucionalidade da Resolução 07/2005 que veda o nepotismo no Poder Judiciário, o que demonstra o entendimento deste Tribunal no sentido de privilegiar o princípio da moralidade administrativa. (BRASIL, STF. RExt. 423.560, Rel. Min. Joaquim Barbosa, 2012).

Apesar de o nepotismo em si não ser o caso direto da decisão proferida pelo Supremo Tribunal Federal, como dito, a vedação imposta pelos Municípios de São Tiago e de Brumadinho revelam-se como tentativas do Estado para efetivar o princípio da moralidade, afastando a incidência de interesses pessoais por parte de dos detentores de mandatos eletivos no âmbito do executivo e do legislativo, bem como de administradores e servidores sobre o interesse público.

\section{CONCLUSÃO}

A revisão bibliográfica e documental apresentada, a partir do estudo do Recurso Extraordinário $\mathrm{n}^{\circ} 423.560$ como marco teórico, permite deduzir, à guisa de conclusão, que diante das regras processuais contidas no CPC de 2015 a Fazenda Pública pode utilizar a técnica dos negócios jurídicos processuais judicial ou extrajudicialmente.

Assim, a partir da metodologia utilizada, foi possível construir uma noção geral de como se organiza a federação brasileira, apresentando, especialmente, o cenário no qual estão 
inseridos os Municípios, sendo que a maioria deles tem população inferior a 20 (vinte) mil habitantes e depende de repasses dos outros entes federados, o que pode comprometer a administração como um todo. Ainda nessa primeira abordagem foi verificada a obrigação de todos os entes e órgãos da Administração Pública, incluindo os Municípios, em adquirir seus bens e contratar seus serviços por meio de processos licitatórios.

Adiante, foi analisada a distribuição do poder normativo previsto na Constituição da República, sendo que nela existem vários dispositivos que delimitam o campo de atuação de cada ente, especificando-se as respectivas matérias.

O nepotismo também foi abordado, mesmo que de forma sumária, com vistas a verificar que a sua incidência foi alvo de rechaço por parte do Poder Judiciário, sobretudo, a partir da edição da Súmula Vinculante $\mathrm{n}^{\circ} 13$, a qual representou um marco no combate à imoralidade administrativa no que diz respeito ao abuso praticado por parte de alguns agentes públicos quando de nomeação de parentes para ocupar cargos públicos em inobservância aos ditames constitucionais e legais.

A partir da análise do Recurso Extraordinário no 423.560 foi possível verificar que o entendimento acerca dos limites da competência legislativa suplementar ainda era controverso até chegar ao Supremo Tribunal Federal, haja vista que o caso concreto analisado demonstrou que num primeiro momento a norma foi declarada inconstitucional pelo Tribunal de Justiça de Minas Gerais, sendo então reformada pela Suprema Corte.

Os dados e fundamentos trabalhados, desde a compreensão da organização da federação brasileira e do dever de licitar por parte de todos os entes e órgãos da Administração Pública, passando pela análise da distribuição do poder normativo previsto na Constituição, do conceito e aplicação do nepotismo e da análise detida do Recurso Extraordinário $\mathrm{n}^{\circ} 423.560$, serviram para confirmar a hipótese suscitada inicialmente, qual seja: que os Municípios podem suplementar a legislação federal sobre licitações para estipular vedações à participação nos certames licitatórios.

Como visto, a prática do nepotismo pode se dar de diversas formas (direta, indireta, cruzada e trocada), mas também pode ser realizado de forma dissimulada, como é o caso das contratações públicas. Assim, a decisão do Supremo Tribunal Federal contém expressiva orientação para todos os entes da federação, em especial os Municípios, os quais, como deflagrado, possuem, em sua maioria, menos habitantes e, consequentemente, menos condições financeiras de ter uma boa estrutura administrativa como um todo. 
Dessa forma, o caso prático analisado demonstra que objetivamente o Estado tem perseguido alcançar eficácia no combate ao nepotismo, em todas as suas formas de aplicação, sendo que a busca pela concretização do princípio constitucional da moralidade administrativa deve ser uma preocupação bilateral, ou seja, tanto do administrador, quando do administrado.

\section{REFERÊNCIAS}

ACQUAVIVA, Marcus Cláudio. Dicionário jurídico Acquaviva. 3.ed. São Paulo: Rideel, 2009.

BRASIL. Controladoria Geral da União. Perguntas e respostas. Disponível em: https://www.cgu.gov.br/assuntos/etica-e-integridade/nepotismo/perguntas-e-respostas\#nepo5. Acesso em: 08 mar. 2019.

BRASIL. Constituição (1988). Constituição da República Federativa do Brasil. Disponível em: http://www.planalto.gov.br/ccivil_03/constituicao/ConstituicaoCompilado.htm. Acesso em: 08 mar. 2019.

BRASIL. Constituição (1988). Emenda Constitucional nº19, de 04 de junho de 1998. Modifica o regime e dispõe sobre princípios e normas da Administração Pública, servidores e agentes políticos, controle de despesas e finanças públicas e custeio de atividades a cargo do Distrito Federal, e dá outras providências. Disponível em:

http://www.planalto.gov.br/ccivil_03/constituicao/Emendas/Emc/emc19.htm\#art1 . Acesso em: 08 mar. 2019.

BRASIL. Constituição (1988). Emenda Constitucional n45, de 04 de junho de 1998. Altera dispositivos dos arts. $5^{\circ}, 36,52,92,93,95,98,99,102,103,104,105,107,109,111$, 112, 114, 115, 125, 126, 127, 128, 129, 134 e 168 da Constituição Federal, e acrescenta os arts. 103-A, 103B, 111-A e 130-A, e dá outras providências. Disponível em: http://www.planalto.gov.br/ccivil_03/constituicao/Emendas/Emc/emc19.htm\#art1 . Acesso em: 08 mar. 2019.

BRASIL. Decreto $\mathbf{n}^{\mathbf{0}} \mathbf{7 . 2 0 3}$, de 4 de junho de 2010. Dispõe sobre a vedação do nepotismo no âmbito da administração pública federal. Disponível em:

http://www.planalto.gov.br/ccivil_03/_Ato2007-2010/2010/Decreto/D7203.htm. Acesso em: 08 mar. 2019.

BRASIL. Lei no 4.657, de 4 de setembro de 1942. Lei de introdução às normas do Direito Brasileiro. Disponível em: http://www.planalto.gov.br/ccivil_03/decretolei/del4657compilado.htm. Acesso em: 08 mar. 2019.

BRASIL. Lei no 8.666, de 21 de junho de 1993. Regulamenta o art. 37, inciso XXI, da Constituição Federal, institui normas para licitações e contratos da Administração Pública e dá outras providências. Disponível em:

http://www.planalto.gov.br/ccivil_03/LEIS/L8666cons.htm. Acesso em: 08 mar. 2019. 
BRASIL. Lei no 10.520, de 21 de junho de 1993. Institui, no âmbito da União, Estados, Distrito Federal e Municípios, nos termos do art. 37, inciso XXI, da Constituição Federal, modalidade de licitação denominada pregão, para aquisição de bens e serviços comuns, e dá outras providências. Disponível em:

http://www.planalto.gov.br/ccivil_03/LEIS/2002/L10520.htm. Acesso em: 08 mar. 2019.

BRASIL. Supremo Tribunal Federal. Norma que proíbe contrato entre parentes de dirigentes municipais e prefeitura é constitucional. RExt. 423.560. Rel. Min. Joaquim Barbosa. Brasília, 2012. Disponível em: http://portal.stf.jus.br/processos/detalhe.asp?incidente=2219673.

Acesso em: 08 mar. 2019.

BRASIL. Supremo Tribunal Federal. Súmula Vinculante 13. Brasília, 2008. Disponível em: http://www.stf.jus.br/portal/jurisprudencia/menuSumario.asp?sumula=1227. Acesso em: 08 mar. 2019.

BRUMADINHO. Lei Orgânica Municipal, de 20 de março de 1990. Disponível em: https://www.cmbrumadinho.mg.gov.br/legislacao/lei-organica-municipal. Acesso em: 08 mar. 2019.

BRUMADINHO. Lei Orgânica Municipal, de 27 de dezembro de 2018. Disponível em: https://www.cmbrumadinho.mg.gov.br/legislacao/lei-organica-municipal. Acesso em: 08 mar. 2019.

CASTRO, José Nilo de. Direito municipal positivo. 6. ed. rev. atual. Belo Horizonte: Del Rey, 2006.

COSTA, Jorge Heleno. O federalismo brasileiro e a (in)aplicabilidade do instituto das convenções processuais no âmbito da fazenda pública municipal a partir da perspectiva do Código de Processo Civil de 2015. In: IX ENCONTRO INTERNACIONAL DO CONPEDI - QUITO. Florianópolis: CONPEDI, 2018, p. 102-122. Disponível em: http://conpedi.danilolr.info/publicacoes/5d6x83my/z9927m21/C499S23Xk6h1F0mr.pdf. Acesso em: 03 mar. 2019.

COSTA, Jorge Heleno.; PINTO, Lucas Baffi Ferreira . Teoria da democracia e da filosofia do estado e direito constitucional. In: Armando Albuquerque de Oliveira; Lucas Gonçalves da Silva; Matheus Felipe De Castro; Rubens Beçak. (Org.). A (im)postergável revolução do pacto federativo brasileiro analisado à luz da teoria paradigmática de Thomas Kuhn. 1ed.Zaragoza: Prensas de la Universidad de Zaragoza, 2019, v. 22, p. 11-32.

FERNANDES, Jorge Ulisses Jacoby. Sistema de registro de preços e pregão presencial e eletrônico. 2. ed. Belo Horizonte: Fórum, 2007.

JUSTEN FILHO, Marçal. Comentários à lei de licitações e contratos administrativos. 14.ed. São Paulo: Dialética, 2010.

JUSTEN FILHO, Marçal. Pregão: comentários à legislação do pregão comum e eletrônico. 4. ed. São Paulo: Dialética, 2005.

LENZA, Pedro. Direito constitucional esquematizado. 21.ed. São Paulo: Saraiva, 2017. 
MEIRELLES, Hely Lopes. Direito municipal brasileiro. 16. ed. atual. São Paulo: Malheiros, 2008 .

MINAS GERAIS. Constituição (1989). Constituição do Estado de Minas Gerais. Disponível em: https://www.almg.gov.br/consulte/legislacao/completa/completa-novamin.html?tipo=CON\&num=1989\&ano=1989. Acesso em: 08 mar. 2019.

MINAS GERAIS. Tribunal de Justiça. ADI 1.0000.00.287271-1/000. Rel. Des. Francisco Figueiredo, 2003. Disponível em:

https://www5.tjmg.jus.br/jurisprudencia/pesquisaPalavrasEspelhoAcordao.do?\&numeroRegis tro $=6 \&$ totalLinhas $=6 \&$ paginaNumero $=6 \&$ linhasPorPagina $=1 \&$ palavras $=$ parentesco $\% 20$ contr ata\%E7\%E3o\%20munic\%EDpio.\%20proibi\%E7\%E3o\&pesquisarPor=ementa\&orderByData $=2 \&$ referenciaLegislativa $=$ Clique $\% 20$ na $\% 201$ upa $\% 20$ para $\% 20$ pesquisar $\% 20$ as $\% 20$ refer $\%$ EA ncias\%20cadastradas...\&pesquisaPalavras=Pesquisar\&. Acesso em: 08 mar. 2019.

MOVIMENTO DEMOCRÁTICO BRASILEIRO. Estatuto, 2017. Disponível em: https://www.mdb.org.br/estatuto/. Acesso em: 08 mar. 2019.

RANGEL, Tauã Lima Verdan. Os princípios da moralidade e da impessoalidade como estertores combativos ao nepotismo. In: Âmbito Jurídico, Rio Grande, XXI, n. 169, fev 2018. Disponível em: http://www.ambito-

juridico.com.br/site/index.php?n_link=revista_artigos_leitura\&artigo_id=20169\&revista_cad erno=4. Acesso em: 08 mar. 2019.

RODRIGUES, João Gaspar. Nepotismo no serviço público brasileiro e a SV13. Revista de Direito Administrativo, Rio de Janeiro, v. 260, p.203-229, maio/ago. 2012. ISSN 00348007. Disponível em: http://bibliotecadigital.fgv.br/ojs/index.php/rda/article/view/8835/7628. Acesso em: 08 mar. 2019.

SÃO TIAGO. Lei Orgânica Municipal, de 10 de janeiro de 2003. Disponível em: http://www.camarasaotiago.mg.gov.br/Especifico_Cliente/26148106000120/Arquivos/files/L ei\%200rganica/Lei_Organica_Atualizada.pdf. Acesso em: 08 mar. 2019. 